Mond is president, was held in Paris on June 27-30. It was attended by a number of distinguished archæologists and others interested in the problems of the Sahara from France, Great Britain, Egypt, Italy, Tunis, Morocco and the Sudan. Numerous important communications, illustrated by lantern slides and exhibits, were presented and discussed in the sessions of the Commission. For the first time it was possible for the quaternary problem in the Sahara to be discussed as a whole, without reference to irrelevant political boundaries. Special stress, it would appear from a brief report in the Journal des Débats of July 4, was laid on the geological and geographical unity of the Sahara as a whole from the Nile to the Atlantic, in which the conditions of development, of desiccation, and of life are subject to the same general laws, notwithstanding certain local divergences. Valuable comparisons of observations from west, centre and east were made, and various conclusions emerged. Among these, that from the early palæolithic onward it was not possible to establish exact correspondence between Africa and Europe, and secondly that the succession of the large number of rock engravings and paintings in the Sahara continued down to modern times. The Commission, it will be seen, has thus made a substantial beginning in the important work of synthesis in Saharan studies. The results will appear in a volume, of which the publication has been guaranteed by Sir Robert Mond, who also entertained the members at luncheon at the close of the proceedings. It has been decided that the Commission will meet every fourth year, the business of the Commission in the interval being conducted by Mr. Harper Kelley at the Musée de l'Homme, Paris.

\section{The Czechoslovak Research Council}

During the twenty years of the existence of the Czechoslovak Republic, the university authorities and scientific institutions of that country have not failed to realize the importance of research work in the natural sciences. Among the organizations which have fostered academic investigations is the Czechoslovak National Research Council (Ceskoslovenská Národní Rada Badatelská). This body has just issued its fourteenth annual report, in which reference is made to the work recently published and still in progress. Practically all branches of science are represented, and some of the investigations have been commented upon already in Nature. From the report, too, it is learnt that several prominent Czechoslovak men of science have been invited abroad to describe their special contributions to recent advances in the different sciences. On the other hand, students from various European and American countries have spent some time in the laboratories at Prague and Brno, studying technique in chemistry (polarographic methods), archæology (excavations in Moravia), biology and physies. During the year under review the Council, together with other bodies, arranged for the International Congress for the History of Science which coincided with celebrations of the hundred and fiftieth anniversary of the birth of J. E. Purkyne, the physiologist. The report also refers to the support the National Research Council has given to some fifty students (fourteen of whom were thus able to go abroad), which has permitted certain investigations to be undertaken or prolonged. These include special geological surveys, archæological excavations, a study of certain properties of heavy water, work on genetics, the ecology of certain lake flora, and biochemical examinations of fungal colonies in beech woods.

\section{The Rhodes Scholarships}

THE Rhodes Scholarships statement for 1936-37 shows a distribution of the 185 scholars (93 from the British Empire overseas, 86 from the United States and 6 from Germany), as follows : natural science 56, philosophy, politics and economics ('Modern Greats') 36, law 29, modern history 17, English 14, Litt. Hum. 10, economics 8, mathematics 6, modern languages 3, geography, education and colonial service probationers 2 each. The particulars given of distinctions achieved by former Rhodes scholars are interesting for the light they throw on the question how far the founder's objects are being realized. Every one of the fourteen Americans is described as holding an important position (such as head of, or professor in, a university or college, or member of congress) in America, which accords well with the words in Rhodes's will : "without, I hope, withdrawing them or their sympathies from the land of their adoption or birth". As regards the British Empire (the retention of the unity of which was one of the declared objects of the scholarships) noteworthy appointments mentioned are those of governor of the Canadian Broadcasting Company, solicitor to the Treasury, Ottawa, chancellor of the University of Sydney, director of education, Victoria, director of the Institute of Pathology, Sydney, and Nuffield professor of surgery, Oxford. One of the Germans is professor of economics and political science, University of Heidelberg, and another president of the Academy of Sciences, Munich. "The object", says the will, of the German scholarships, "is that an understanding between the three Great Powers will render war impossible and educational relations make the strongest tie"'.

\section{Canadian Research Scholarships}

FonTY-NINE scholarships have been awarded for 1938-39 by the National Research Council of Canada. Graduates from fourteen Canadian universities have been given awards which will enable them to pursue post-graduate studies at the following universities : Dalhousie, Laval, McGill, Montreal, Queen's, Saskatchewan and Toronto. Four special scholarships will be tenable in the National Research Laboratories at Ottawa, where the holders, who have already gained post-graduate experience in research, will be given an opportunity to put their talents to work on some practical problem such as they may expect to meet when they enter commercial or 
industrial work. For work in the universities, the scholarships granted include one fellowship, seventeen studentships and twenty-seven bursaries. Twentyeight of the awards are to be used in financing graduate students in chemistry, including fourteen in physical chemistry, six in cellulose research, four in organic chemistry, two in general chemistry, one in inorganic chemistry and one on a practical chemical problem in the National Research Laboratories. Twelve candidates will work in physics, including three in the National Research Laboratories. Other divisions of science represented in the awards are: biochemistry, 2 ; biology, 2 ; botany, 1 ; entomology, 1 ; genetics, 2 ; and mathematics, 1.

\section{Rockefeller Travelling Fellowships in Medicine}

THE following Rockefeller travelling fellowships in medicine have been awarded by the Medical Research Council for the academic year 1938-39: R. R. Bomford, assistant physician, London Hospital; T. Colver, outpatient medical registrar, Hospital for Sick Children, Great Ormond Street, London ; R. M. Heggie, assistant lecturer in pathology and bacteriology, Welsh National School of Medicine, Cardiff; Ian MacKenzie, assistant surgeon, St. Giles's Hospital, London; Dr. G. G. E. Smyth, Dickinson research scholar, National Hospital, Queen Square, London; Ivor G. Williams, senior assistant radiotherapist, Meyerstein Institute of Radiotherapy, Middlesex Hospital. All these fellows propose to work at centres in the United States, with the exception of Dr. Smyth, who intends to study in Paris. Dr. Williams will hold his fellowship for six months only. In addition, the Rockefeller Foundation has awarded similar fellowships, on the recom. mendation of the Medical Research Council, to the following candidates in the special field of psychiatry, neurology and related subjects, all of whom are from the Maudsley Hospital, London : T. R. C. Fraser, W. W. Sargant, and M. J. F. McArdle.

\section{The World Power Conference}

WE have received from the Central Office of the World Power Conference, Kingsway, London, the annual report for 1937. Dr. William F. Durand is the president and Sir Harold Hartley is the chairman of the International Executive Council. The first conference was held in London in 1924, the second in Berlin in 1930 and the third in Washington in 1936. In addition, six other special meetings have been held. The next meeting of the council will take place in Vienna on August 29, 1938. The total number of National Committees of the World Power Conference is now 42, and in addition there are four member-countries with representatives. After the conference at Vienna this year there will be a studytour of about a week's duration. The Central Office continues to circulate to the National Committees and representatives, reports on the work being carried on by the International Special Committee on Radio Interference, under the auspices of the International Electrotechnical Commission.
'THE following appointments of official delegates to the sectional meeting of the World Power Conference to be held in Vienna on August 25-September 2, have been made : to represent the Government of the United Kingdom, Sir Harold Hartley (chairman, International Executive Council and chairman, British National Committee of the World Power Conference, and Mr. J. M. Kennedy, deputy-chairman, Electricity Commission; appointed by the British National Committee of the World Power Conference, Sir Archibald Page, chairman, Central Electricity Board, and Dr. F. S. Sinnatt, director of fuel research, Department of Scientific and Industrial Research. The total attendance from the United Kingdom will exceed eighty, which is a record for any sectional meeting of the World Power Conference held abroad.

\section{International Management Congress}

STRoNG British support has been secured for the seventh International Management Congress which meets in Washington, D.C., on September 19-24. More than ninety delegates, fully representative of British industry, are attending to support Lord Leverhulme, who is the president of the International Committee. An interesting unit of this party consists of nine young executives, one of whom is a lady, who are being assisted by bursaries paid out of the funds remaining from the sixth Inter. national Congress held in 1935 in London. This party will travel together as a unit under the leadership of Dr. E. F. Armstrong : it is anticipated that each will profit from the collective experience of the whole. Four tours by motor coach have been organized, enabling the delegates to visit a number of factories and cities. Before the Congress, there is one tour of six days in New England and a second, taking five days, to the highly industrialized country between New York and Washington. After the Congress, an eleven-day tour goes through the midWest to Chicago and back to New York via Buffalo and Niagara, and there is a final short tour to Boston. It is proposed to give some form of written report of the visits, which will serve as a permanent record. The tours are likely to be of exceptional educational value from the point of view of scientific management. About 250 papers from some twenty countries have been accepted by the Congress. The papers of each technical section have been summarized. The chairman of the Congress Council is Mr. Willis H. Booth, vice-president of the Guaranty Trust Company ; that of the Co-ordinating Committee is $\mathrm{Mr}$. William $\mathrm{L}$. Batt, president of S. K. F. Industries; whilst the chairman of the Organizing Committee is Mr. Harry A. Hopf, well known as one of the most active protagonists of the management movement. The delegates will be welcomed by Mr. Cordell Hull, and there will be a formal reception at the White House.

\section{International Scientific Radio Union}

TнE sixth General Assembly of the International Scientific Radio Union (Union Radio Scientifique Internationale) will be held in Italy on September 4-14. The U.R.S.I. is one of the constituent bodies 